\title{
Cretaceous-Tertiary boundary spherules from Denmark, New Zealand and Spain
}

\author{
HANS JØRGEN HANSEN, RAYMOND GWOZDZ, RICHARD G. BROMLEY, KAARE L. RASMUSSEN, EBBE W. \\ VOGENSEN AND KAJ R. PEDERSEN
}

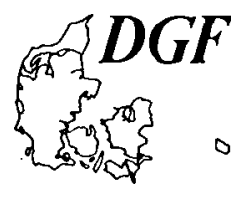

\begin{abstract}
Hansen, H. J., Gwozdz, R., Bromley, R. G., Rasmussen, K. L., Vogensen, E. W. and Pedersen, K. R.: Cretaceous-Tertiary boundary spherules from Denmark, New Zealand and Spain. Bull. geol. Soc. Denmark, vol. 35, pp. 75-82, Copenhagen, October, 29th, 1986.

https://doi.org/10.37570/bgsd-1986-35-09

Spherules from the Cretaceous-Tertiary boundary layers in Denmark, New Zealand and Spain have been studied with respect to their content of organic material. After dissolution in $\mathrm{HCl}$ and $\mathrm{HF}$, organic spheres were found. According to their morphology and structure they belong to the green algal group Prasi- nophyta. The mineralogical composition of the spherules is dominated by goethite in the Danish and New Zealand examples while those from Spain show a combination of sanidine and goethite. It is concluded that the spherules are the result of diagenetic infill of prasinophyte algae and are unrelated to bolide con-densates, micrometeorites, impact glass, and glassy droplets from volcanism on the moon.
\end{abstract}

H. J. Hansen, R. Gwozdz, R. G. Bromley, E. W. Vogensen, Geological Central Institute, Oster Voldgade 10, Copenhagen, DK-1350, Denmark. K. L. Rasmussen, Geophysical Institute, Haraldsgade 6, Copenhagen, DK-2200, Denmark. K. R. Pedersen, Geological Institute, Universitetsparken, Ärhus, 8000, Denmark. April 24th, 1986.

\section{Introduction}

Spherules recovered from Cretaceous-Tertiary boundary strata have been interpreted as being ablation products of meteoritic material or microtektites associated with a presumed impact of a large bolide at the Cretaceous-Tertiary transition (Smit \& Klaver, 1981, Nazarov et al., 1983, Smit \& Romein, 1985).

Detailed studies of some spherules (Montanari et al., 1984, Brooks et al., 1985) have indicated that they should instead be considered diagenetically altered microtektites or bolide ablation products.

This paper reports the results of detailed analysis of spherules from Denmark, New Zealand and Spain.

Methods

Bulk samples were treated according to standard palynological methods. Single specimens were treated with either $5 \%$ or $37 \% \mathrm{HCl}$ for 24 hours followed by rinse in distilled water. This was followed by treatment in $40 \%$ HF for 24 hours, followed by $\mathrm{HCl}$ treatment and finally transfer to water.

After acid treatment, specimens were pro- cessed for ultrasectioning according to standard procedures involving fixation, dehydration and embedding in epoxy resin. Ultrasections were cut with a diamond knife on an LKB ultramicrotome. The sections were post-stained with $\mathrm{Pb}$ and $\mathrm{U}$ and examined in a Hitachi HU Il C transmission electron microscope. Specimens for scanning electron microscopy were air dried, coated with $200 \AA$ pure gold and examined in a Cambridge IIa or 180 microscope.

Spherule mineralogy was determined by mounting single specimens on thin glass needles. These were placed in a Gandolfi X-ray diffraction camera and irradiated by filtered $\mathrm{Cr}_{\mathrm{k}_{\alpha}}$ radiation for 6 hours.

Organic material after dissolution of spherules was examined in dry state under a fluorescence microscope.

\section{Observations}

\section{Denmark}

Pl. 1, figs $1-6$, pl. 2, figs $1-3$.

In Denmark, at Stevns Klint, Karlstrup Quarry, Danian Quarry Nye Kløv and Kjølby Gaard 


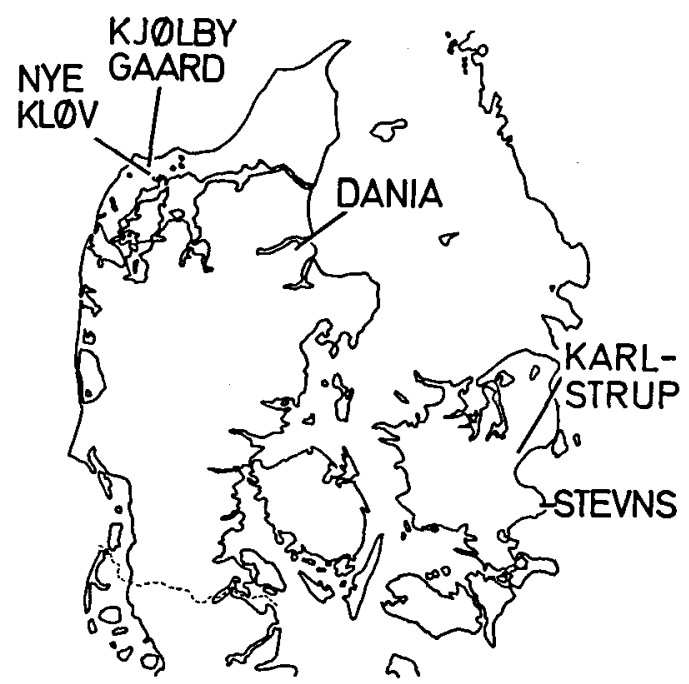

Fig. 1. Map of Denmark showing localities mentioned in the text.

(fig. 1) spherules occur in the Fish Clay at the Mesozoic/Cenozoic boundary.

At Stevns Klint they are most common in the rust-coloured basal part of the Fish Clay. The rust-coloured layer is composed of semi-filled burrows, compressed lenses of which occur higher in the Fish Clay. At the bottom of the Fish Clay they do not form a coherent layer. The spherules from this layer are composed mainly of goethite. Only a few examples of pyrite spherules are found. The spherules also occur embedded in a rust-coloured matrix that consists predominantly of remnants of the green alga Botryococcus. The spherules are found also in the burrows higher up in the fish Clay and even in the overlying Cerithium Limestone.

The spherules may be extracted by gentle application of a preparation needle. In the SEM they show a surface with a porous structure, while others are smooth. Many spherules after dissolution in $\mathrm{HCl}$ left an organic sphere. Such spheres were embedded and ultrasectioned. They demonstrated in the TEM a structure similar to that of prasinophyte algae. The organic spheres seem to be constructed of two layers: An inner layer with a thickness of a few microns with dense perforations. This material showed little affinity to electron microscopic contrast media. The outer wall by contrast took up the contrasting media willingly. The outer layer is about $50 \mathrm{mi}-$ crons thick in cross section and is finely perforated. The difference in acceptence of contrasting media is interpreted as being related to composition. Fatty substances generally absorb these agents more readily than do cellulose or pectic material.

The mineralised spherules show lamellar construction in section or on naturally fractured faces. The lamellae fill up the spherical geometry from the surface inwards to leave a central cavity of variable extent. Thus, all variations from a thin shell to almost massive structures are found.

This type of construction contrasts with that found in oolitic structures where lamellae are deposited onto a nucleus leading to a spherical or almost spherical geometry. In the present case, apparently the opposite process takes place and leads to a pseudo-oolitic construction.

Spherules identical to those from Stevns Klint are found in the Fish Clay from three localities in Jylland. Treatment of these with $\mathrm{HCl}$ also led to the recovery of presumed prasinophyte algal spheres identical to those from Stevns Klint.

Many of the spherules from the Danish localities are equipped with a small circular opening. This we interpret as representing the position of an original pylome.

At only one locality (Karlstrup Quarry in the southern outskirts of Copenhagen) was there a clear difference in mineralogical composition. At this locality all spherules are composed of pyrite. Like the spherules from Stevns Klint they occur

PLATE 1.

Figs. 1-6. Spherules from reddish brown burrow at the bottom of the black Fish Clay at Harvig, Stevns Klint.

Fig. 1. Goethite spherule. Scalebar $100 \mu \mathrm{m}$.

Fig. 2. Detail of Fig. 1 showing outer porous organic layer. Scalebar $10 \mu \mathrm{m}$.

Fig. 3. Hollow goethite spherule with presumed pylome. Scalebar $200 \mu \mathrm{m}$.

Fig. 4. Hollow carbonate impregnated spherule artificially fractured. Note porous outer layer and laminated wall. Scalebar $10 \mu \mathrm{m}$.

Fig. 5. Fractured goethite spherule showing pseudo-oolitic lamination leaving the centre empty. Scalebar $100 \mu \mathrm{m}$.

Fig. 6. Transmission electron micrograph of organic sphere left after treatment of goethite spherule with weak HCl. The contrast-rich dark layer presumably is part of the thick outer lipoid cyst. The perforate, much less contrasty presumably pectic layer still contains crystallites. Scalebar $2 \mu \mathrm{m}$. 

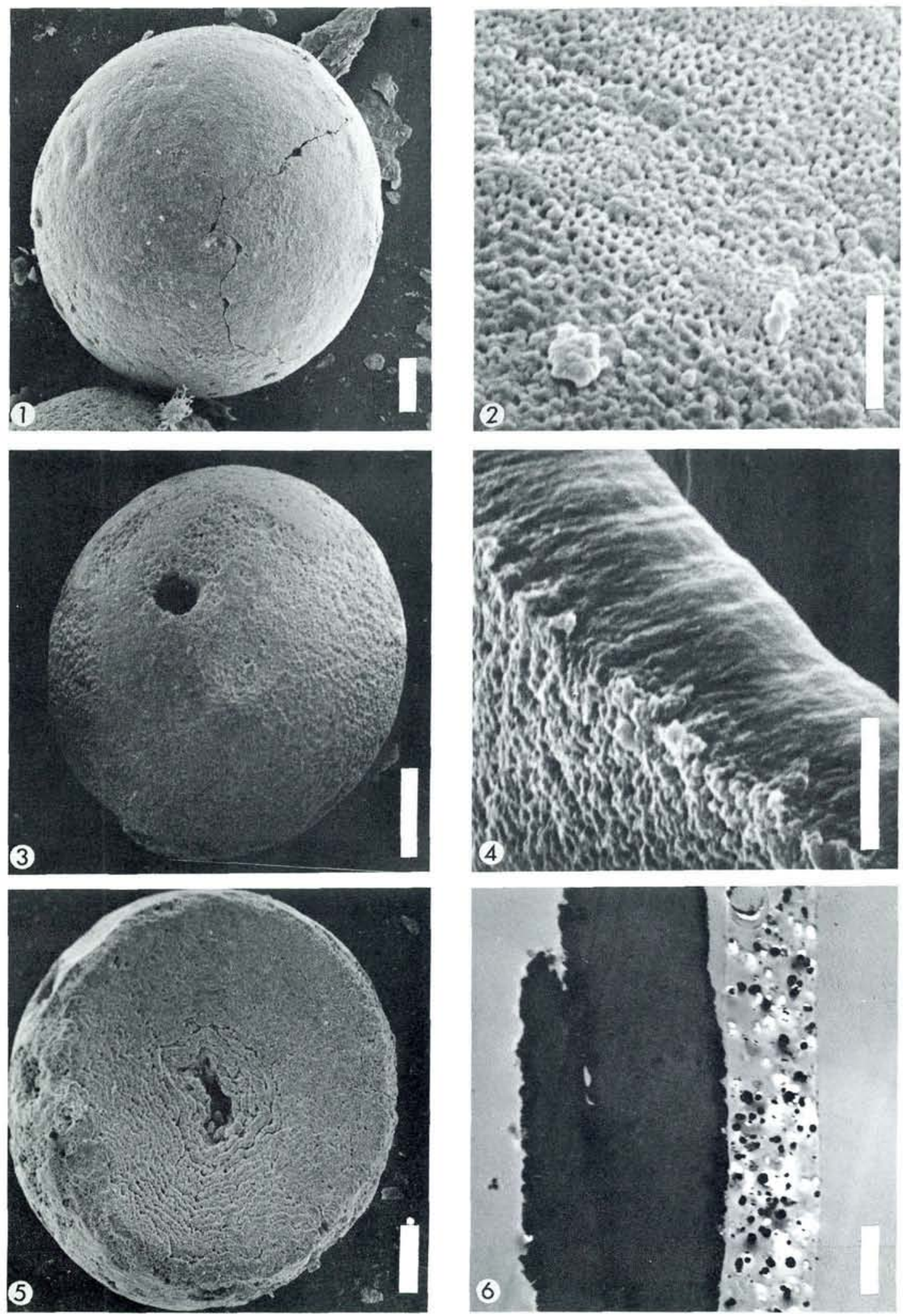
in semi-filled burrows, but here the matrix consists of almost colourless Botryococcus material. The prasinophyte algal remains, however, easily can be extracted from these burrows by application of standard palynological preparation procedures. The pyrite spherules also occur in the Fish Clay and are not confined to the burrows.

C. Heinberg (pers. comm.) called our attention to the existence in the top of the hardened Upper Maastrichtian white chalk bryozoan bioherms at Stevns Klint of burrows filled with solidified micrite and large numbers of spherical cavities with diameters corresponding to those of prasinophyte algae. Apparently the empty algae vanished and left only the spherical impressions in the micritic material.

\section{New Zealand}

\section{Pl. 2, figs 4-6.}

Spherules from the rust-coloured CretaceousTertiary boundary deposits at Woodside Creek were extracted manually. Their mineralogy and chemistry recently were described by Brooks et al. (1985), but the large-diameter type of spherules described by them were not found.

The smaller spherules, with diameters less than $500 \mu \mathrm{m}$, were dissolved in $\mathrm{HCl}$. They left organic spheres, which in ultrasections showed structures identical to those found in the specimens from Denmark.

\section{Spain}

\section{Pl. 3, figs 1-6.}

Sanidine spherules from the Cretaceous-Tertiary boundary layers at Caravaca in Spain have a somewhat uneven and irregular surface. They may be somewhat deformed, almost lens-shaped, probably resulting from post-depositional compression. Many examples have a rust-coloured interior and appear to be constructed of an inner iron-rich core region surrounded by pale sanidine forming a crust, which may constitute a considerable part of the spherule diameter.

Spherules from Caravaca were placed in $37 \%$ $\mathrm{HCl}$ and after 24 hours transferred to $40 \% \mathrm{HF}$ for an additional 24 hours. This treatment yielded organic spheres, or pieces thereof, with diameters considerably smaller than those of the spherules. Some sanidine spherules only left pieces of organic material with prasinophyte structure, but some left spheres of organic material corresponding well with the shape of the original sanidine spherule.

The organic material showed distinct fluorescense under the UV microscope, indicating that they had not undergone even moderate heat-alteration.

An air-dried specimen was seen in the SEM to be constructed of porous organic material apparently with pores of different diameters. It should be remembered, however, that during drying a shrinkage of around $30 \%$ of the original wet diameter takes place.

In a wet state, the difference in diameter between that of the mineralized spherule and the corresponding organic sphere is $30 \%$ or more in most cases.

The sanidine spherules apparently represent prasinophyte algae that have been filled by ironrich material (like Danish examples) and have received a sanidine overgrowth later during diagenesis.

PLATE 2.

Figs. 1-2. Spherules from Karlstrup Quarry, south of Copenhagen.

Fig. 1. Light micrograph showing pyrite spherules in a matrix of bright Botryococcus remains. Scalebar $1000 \mu \mathrm{m}$.

Fig. 2. Fractured pyrite spherule with almost euhedral pyrite crystals on the cavity wall. Scalebar $20 \mu \mathrm{m}$.

Fig. 3. Burrowfill from the top of the Maastrichtian white chalk with presumend prasinophyte algal impressions. Scalebar $2000 \mu \mathrm{m}$.

Figs. 4-6. Spherules from Woodside Creek, New Zealand.

Fig. 4. Goethite spherule with slightly corroded outer surface. Scalebar $100 \mu \mathrm{m}$.

Fig. 5. Organic sphere left after dissolution of goethite spherule by HCl. Light micrograph. Scalebar $100 \mu \mathrm{m}$.

Fig. 6. Transmission electron micrograph of sectioned organic sphere left after treatment of goethite spherule. Note the adhearing contrast-rich layer on the inner porous presumend pectic layer with much less contrast. Minor crystals still remain in some pores. Scalebar $3 \mu \mathrm{m}$. 

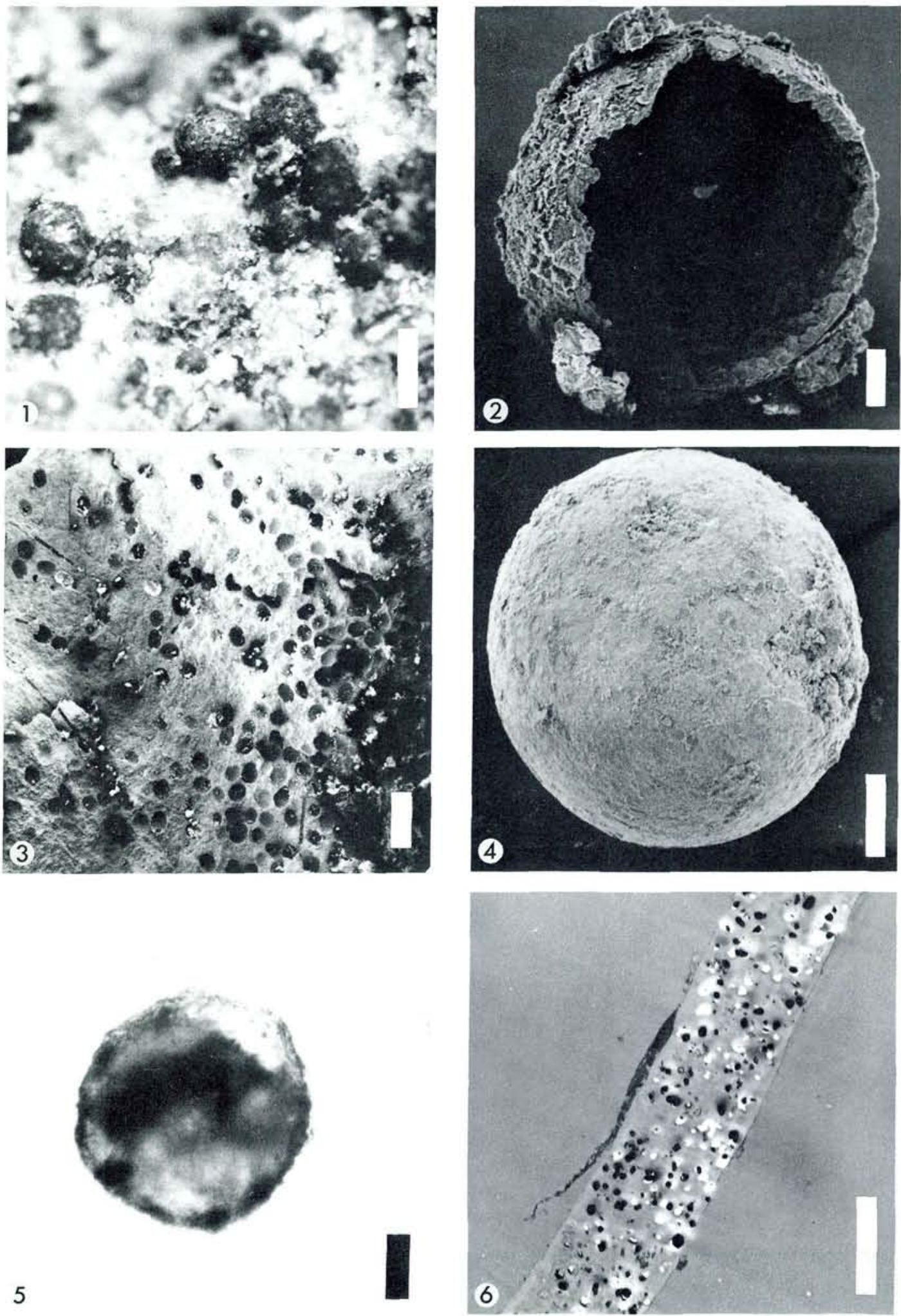


\section{Discussion and conclusions}

Spherules from the Cretaceous-Tertiary boundary layers in Denmark, New Zealand and Spain were found to contain or be contained in algal remains. The thick, fatty, outer wall and the thin inner pectic or cellulose wall strongly points in the direction of the algal group Prasinophyta. It appears that the spherules owe their shape to the original shape of the algae and that the dead algae fell to the sea floor in different stages of development. Thus, the early stages (i.e., those with the smallest diameters) may have their lipoid outer walls preserved, while the larger specimens are surrounded only by the pectic inner layer. In the living representatives of the prasinophytes the thick, fatty, outer finely laminated layer, after having arrived at its final size, opens according to a pre-existing furrow and releases the inner pectic thin-walled sac containing swarmers. With the growth of the flagellated swarmers, the perforated pectic sac becomes inflated, and in the living cell finally "explodes" and lets the swarmers free, so that a new cycle may be initiated. (Parke et al. 1978 fide Tappan, 1980).

The morphology of the Cretaceous-Tertiary boundary spherules is readily understood in the light of the life cycle of the recent prasinophytes. The perfect spheres without any openings or pits thus represent different stages of algae that have not "hatched", while many of those with an opening may represent forms that were only empty algal skeletons. This also explains the wide size range of the spherules, since the algae in the relevant part of their life cycle gradually grow to the size where they finally "explode".

It is interesting to note that the prasinophyte algae have been described as being "disaster species", often occurring in large numbers when the remaining part of the plankton population has a major decline in earth history (Tappan, 1980).
This fits well with the situation at the CretaceousTertiary boundary, where the planktonic foraminifera became extinct.

In view of the finds of organic spheres in the mineral spherules from Denmark, New Zealand and Spain an interpretation of these as being bolide condensates, micrometeorites, impact glass or droplets from lunar volcanism appears unlikely (Smit \& Klaver, 1981, Nazarov et al., 1983, Smit \& Romein 1985, Montanari et al., 1983, Brooks et al., 1985, O'Keefe, 1985).

Acknowledgements. The authors want to express their gratitude to Dr. J. Smit, Holland for the sample of sanidine spherules from Caravaca, Spain, and to Dr. R. R. Brooks, New Zealand, for putting a sample of the Woodside Creek material at our disposal.

The ultrasections were made at the Institute of Anatomy, University of Århus. Discussions with Dr. C. Heinberg is acknowledged. The X-ray diffractometry was kindly made by Dr. E. Leonardsen, Geological Central Institute, Copenhagen. The electron microscopes have been granted by the Danish Natural Science Research Council.

The paper has been reviewed by Dr. T. Ekdale, Utah, Dr. F. Rögl, Wienna, and Dr. W. Riegel, Göttingen. Their suggestions and critisism greatly helped to improve the manuscript.

Since the senior author of the present paper is also the editor of this journal, the chairman of the Geological Society of Denmark has acted as editor of this article.

\section{Dansk sammendrag}

Sfæruler eller småkugler har i de senere år været beskrevet fra mange grænselag mellem kridt og tertiærtid. Kuglerne er blevet tolket som mikrometeoritter eller smeltedråber af jordisk materiale eller en blanding af begge dele afstedkommet af et postuleret stort meteoritfald. Et enkelt forslag er gået ud på, at kuglerne skulle stamme fra explosiv månevulkanisme, hvor smeltedråber er blevet indfanget af jordens tyngdefelt. Meteorfaldet er blevet sat $i$ forbindelse med den store uddøen af dyrearter ved netop kridt-tertiær grænsen.

Sfæruler fra kridt-tertiær grænselag i Danmark, New Zealand og Spanien har været til rådighed for undersøgelser. Fra alle tre områder viser sfærerne sig at indholde eller være omgivet af kugleformede algerester.

Det konkluderes derfor, at de nævnte kugler næppe er meteordråber, mikrotektitter eller størknede dråber fra eksplosiv månevulkanisme men er diagenetiske udfyldninger af de kugleformede alger.

\section{PLATE 3.}

Figs. 1-6. Spherules and spheres from Caravaca, Spain.

Fig. 1. Spherule with rather uneven surface. Scalebar $100 \mu \mathrm{m}$.

Fig. 2. Somewhat corroded spherules with hole that possibly represents a trace of the pylome. Scalebar $100 \mu \mathrm{m}$.

Fig. 3. Light micrograph of organic algal wall. Note the pores (arrow). Scalebar $10 \mu \mathrm{m}$.

Fig. 4. Somewhat compressed prasinophyte alga left after dissolution of sanidine spherule in $\mathrm{HCl}$ and $\mathrm{HF}$. Scalebar $50 \mu \mathrm{m}$.

Figs. 5-6. Details of fig. 4 showing larger and smaller pores. Fig. 5 scalebar $3 \mu \mathrm{m}$. Fig. 6 . Scalebar $2 \mu \mathrm{m}$. 

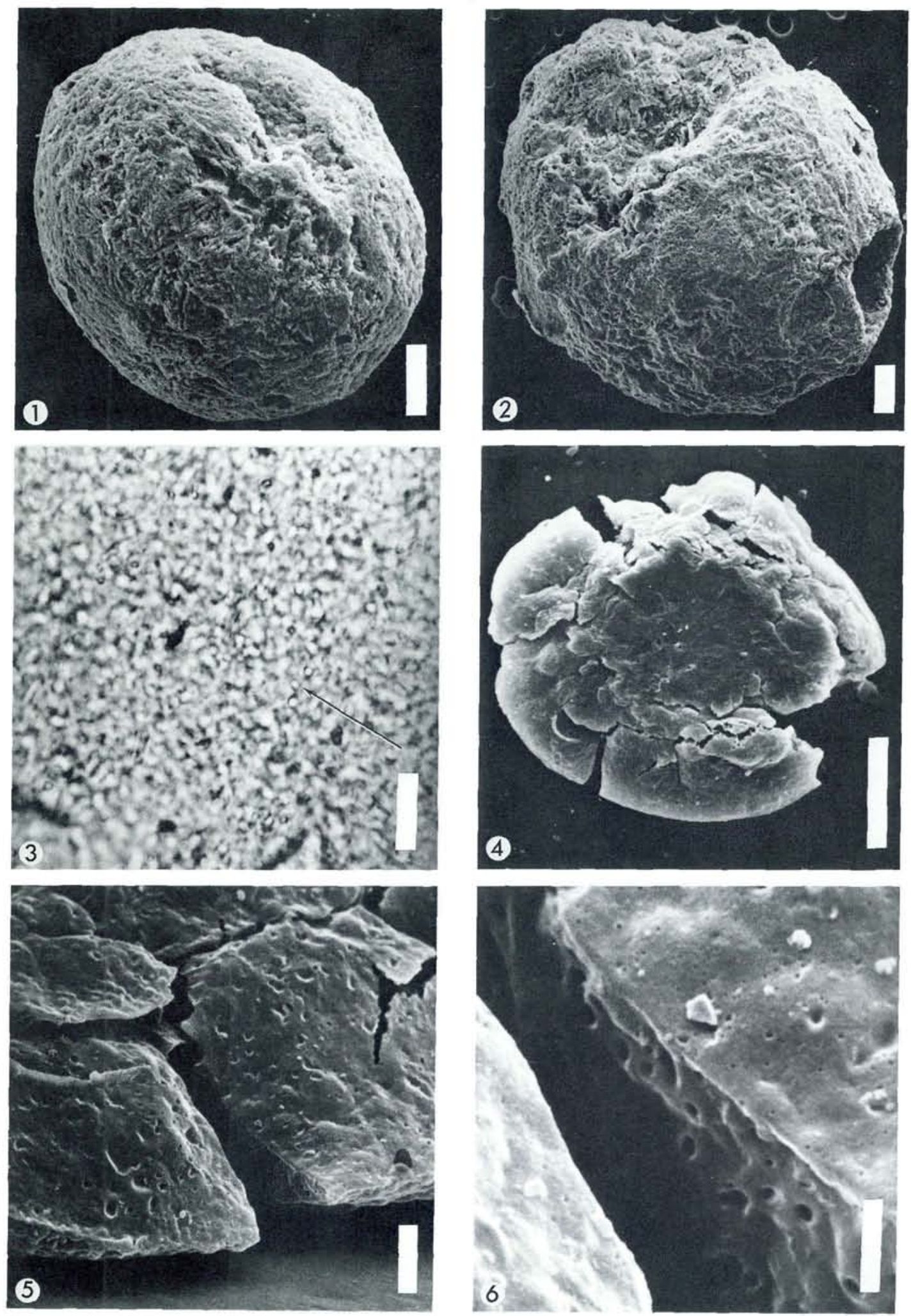


\section{References}

Brooks, R. R., Hoek, P. L., Reeves, R. D., Wallace, R. C., Johnston, J. H., Ryan, D. E., Holzbecher, J. \& Collen, J. D. 1985: Weathered spheroids in a Cretaceous/Tertiary boundary shale at Woodside Creek, New Zealand. Geology, 13, 738-740.

Montanari, A., Hay, R. L., Alvarez, W., Asaro, F., Michel, H. V., Alvarez, L. W. \& Smit, J. 1983: Spheroids at the Cretaceous-Tertiary boundary are altered impact droplets of basaltic composition. Geology, 11, 668-671.

Nazarov, M. A., Barsukova, L. D., Kolesov, G. M., Naidin, D. P. \& Alekseev, A. S. 1983: Origin of iridium anomaly at the Maastrichtian-Danian Boundary. Geochimija, 8, 1160-1178. Akad. Nauk SSSR (in Russian).
O'Keefe, J. A. 1985: The terminal Cretaceous event: Circumterrestrial rings of tektite glass particles? Cretaceous Res. 6, 261-269.

Smit, J. \& Klaver, G.: 1981: Sanidine spherules at the Cretaceous-Tertiary boundary indicate a large impact event. $\mathrm{Na}$ ture, 292, 47-49.

Smit, J. \& Kyte, F. T. 1984: Siderophile-rich magnetic spheroids from the Cretaceous-Tertiary boundary in Umbria, Italy, Nature, 310, 403-405.

Smit, J. \& Romein, A. J. T. 1985: A sequence of events across the Cretaceous-Tertiary boundary. Earth Planet. Sci. Let. $74,155-170$.

Tappan, H. 1980: The paleobiology of plant protists. $1028 \mathrm{pp}$. Freeman \& Co., San Francisco. 